\title{
Fabrication of dye Rhoeospathacea with concentration variation in dye-sensitized solar cells (DSSC)
}

\author{
Sri Sumardiasih ${ }^{1}$, Agus Supriyanto ${ }^{2}$, Cari $^{2}$ \\ ${ }^{1,2}$ Physics Department of Post Graduate Program, Sebelas Maret University \\ J1. Ir. Sutami 36A, Kentingan Surakarta \\ Email: usagi20389@gmail.com
}

Received 26 October 2016, Revised 28 November 2016, Accepted 5 January 2017

\begin{abstract}
Dye-sensitized solar cell (DSSC) is a device that directly converts visible light into electrical energy. In this work we used dye was extracted from Rhoeo spathacea. A natural dye was directly mixed with $\mathrm{TiO}_{2}$ anatase to obtain dyed titanium dioxide which can be used as photoanode for DSSC by varying the volume of dye. The first variation is $2 \mathrm{ml}$ dye mixed with 1 $\mathrm{ml}$ of $\mathrm{TiO}_{2}$, and the second variation is $3 \mathrm{ml}$ dye mixed with $1 \mathrm{ml}$ of $\mathrm{TiO}_{2}$. The absorbance spectra of the dye and dye titanium dioxide have been investigated by spectroscopy UV-Visible Lambda 25 and the conversion efficiency of dye titanium dioxide used Keithley 2602A meter. The DSSC based on dye titanium dioxide with varying volume of dye showed that the efficiency of the the second variation is $0,033 \%$ which is higher than the first variation $(0,023 \%)$ as obtained from I-V characterization.
\end{abstract}

Keywords : direct mixing dye with $\mathrm{TiO}_{2}$; Rhoeo spathacea; DSSC

\section{Introduction}

In 1991, Gratzel and O'Regan succeeded in developing a new type of solar cell, known as Dye-Sensitized Solar Cell (DSSC). Dye-sensitized solar cell (DSSC) is a device that directly converts solar radiation into electrical energy. The DSSC consists of nano crystalline titanium dioxide $\left(\mathrm{TiO}_{2}\right)$ layer, the dye molecule layer that absorbed by $\mathrm{TiO}_{2}$ surface, an electrolyte which contains iodide/triiodide $\left(\mathrm{I}^{-} / \mathrm{I}_{3}^{-}\right)$, and accounter electrode which acts as a catalyst for electron regeneration (Syafinar et al., 2015).

Dyes in DSSC act as the electron donor and titanium dioxide acts as the electron acceptor. When the sunshine on the dye, the photon of sunlight provides the energy to the electron of dye that makes the excitation electron. Then the excited electrons injected into the conduction band of $\mathrm{TiO}_{2}$ film. The original state of the dye is subsequently restored by the donation of electron from the electrolyte with redox (for example $\mathrm{I}^{-} / \mathrm{I}_{3}{ }^{-}$) system, where it is regenerated at the counter electrode by electrons passing through the load (Gratzel, 2003).

The sensitizer is important in DSSC because can convert the solar radiation into electrical energy. Natural dyes such as pigments used in food coloring can be used in DSSC. Anthocyanin is one of the natural dyes has been used as a sensitizer. Anthocyanin molecule can attach the dye to $\mathrm{TiO}_{2}$ surface due to having carbonyl $(\mathrm{C}=\mathrm{O})$ 
and a hydroxyl group (OH) (Syafinar et al., 2015). Rhoeo spathacea is one of the important sources of anthocyanin because has widely visible light spectrum (Sustia et al., 2013). The most common semiconductor used in DSSC is $\mathrm{TiO}_{2}$ because of its superior properties, inexpensive, like non-toxic, good chemical stability, biocompatibility, etc. The absorption spectra of $\mathrm{TiO}_{2}$ is UV light (Kang and Lee, 2010 ).

The one of an enhancement for the performance of DSSC is the number of dye molecules that can be absorbed by a layer of $\mathrm{TiO}_{2}$. Dye-sensitizer is important in convert the visible light into electrical energy in case of chelate to the $\mathrm{TiO}_{2}$ surface (Smestad and Gratzel, 1998). The number of dye molecules that is absorbed by the $\mathrm{TiO}_{2}$ is affected by the homogeneity of the mixture will determine the quality of the composite bond (Ananth et al., 2014). The quality of composite bonding can be enhanced through the synthesis method. Thus, in this work will make DSSC by direct mixing $\mathrm{TiO}_{2}$ with dye to obtain dye titanium dioxide by varying the volume of dye in the mixing process.

\section{Experimental}

\subsection{Dye Extraction}

In this work using powder natural dyes from anthocyanin extracted from dried Rhoeo spathacea. 5gr Rhoeo spathacea powder, $25 \mathrm{ml}$ ethanol was mixed. The mixture was kept for half an hour at temperature $60^{\circ} \mathrm{C}$ and was kept for 12 hours. The extract was filtered and used for the synthesis of natural dye mixed $\mathrm{TiO}_{2}$.

\subsection{Synthesis of Dye Titanium Dioxide}

The synthesis of dye titanium dioxide using 0,5gr the anatase phase $\mathrm{TiO}_{2}$ nanoparticles, $3 \mathrm{ml}$ ethanol was mixed. The mixture was kept for an hour. Then $\mathrm{TiO}_{2}$ was mixed with dye by volume variations. The first variation is $2 \mathrm{ml}$ dye mixed with 1 $\mathrm{ml}$ of $\mathrm{TiO}_{2}$, and the second variation is $3 \mathrm{ml}$ dye mixed with $1 \mathrm{ml}$ of $\mathrm{TiO}_{2}$. Dye was added dropwise into $\mathrm{TiO}_{2}$ under vigorous stirring at room temperature with equal interval of time. After completing the dropwise addition of dye, the solution was stirred for an hour to obtain a homogeneous solution.

The paste of dye titanium dioxide coated onto the FTO glass with the spin-coating method. The measuring of the absorbance spectra of the dye and dye titanium dioxide using a UV-Vis spectroscopy system (Lambda 25).

\subsection{DSSC Fabrication}

The DSSC consisted of two conductive glass, $\mathrm{TiO}_{2}$ layer, molecules dye, electrolyte and carbon layer (Hemmatzadeh and Mohammadi, 2013).

For the fabrication of the dye titanium dioxide working electrode, a homogeneous paste dye titanium dioxide with variation volume was prepared. The paste of dye titanium dioxide was coated onto the FTO glass with the spin-coating method and sintering at $60^{\circ} \mathrm{C}$ for 30 minutes. The catalytic counter electrode has been prepared with the FTO glass that heat at $90^{\circ} \mathrm{C}$ for 5 minute and $250^{\circ} \mathrm{C}$ for 15 minutes. Then $2.5 \mathrm{ml}$ was added dropwise onto the FTO glass. 
The DSSC are assembled injected with the electrolyte solution and then sealed using the clipboard. To determine the voltage and current of the DSSC was used a Keithley 2602 A meter (USA) under illumination by a lamp of $1000 \mathrm{~W} / \mathrm{m}^{2}$.

\section{Result and Discussion}

\subsection{UV-Vis analysis}

The UV-Vis absorption spectra of dye and dye titanium dioxide with volume variation are given in Figure 1. The absorption spectrum showed that the pure $\mathrm{TiO} 2$ does not absorb the solar radiation above $320 \mathrm{~nm}$ and dye Rhoeo spathacea exhibit a good absorption peak in the visible region at $665 \mathrm{~nm}$ and $413 \mathrm{~nm}$. The absorption peak is showed in the region can more absorb the solar radiation because have more anthocyanin (Kartikasari, 2014). Hence, $\mathrm{TiO}_{2}$ needs a dye sensitizer to become a good solar cell photoanode material. It shows by the natural dye titanium dioxide exhibit a good absorption peak between the end of UV region and the beginning of visible region. Absorption peak is shifting which gets suppressed when dye mixed with $\mathrm{TiO}_{2}$. This implies that these types of dye molecules are strongly bound to the oxide surface (Ananth et al., 2014).

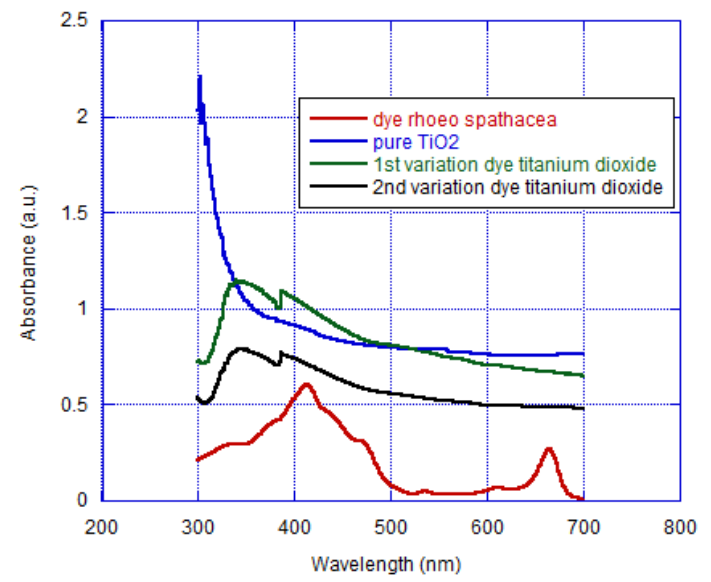

Figure 1. Absorption spectra of pure $\mathrm{TiO} 2$, dye Rhoeospathacea,dye titanium dioxide with $1^{\text {st }}$ and $2^{\text {nd }}$ variation

The quality of bonding was influenced by a homogeneous solution. By increasing the concentration of dye and in wavelength can affect the electron injection into the conduction band of $\mathrm{TiO}_{2}$ (Kartikasari, 2014).

\subsection{Performance of DSSC}

The characteristic of voltage and current of DSSC was a method to determine the efficiecy of DSSC. By inspecting Figure 2, Figure 3, and Table 1, it's shown the performance parameter of DSSC. 


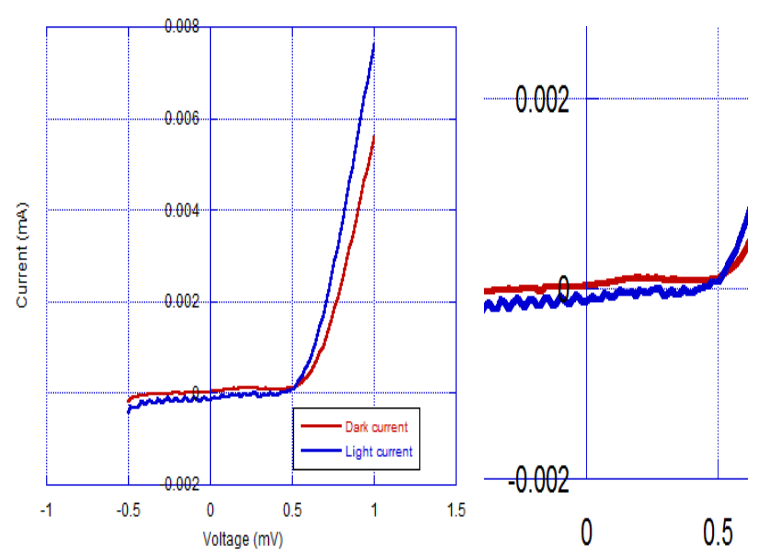

Figure 2. Current-voltage curves of the $1^{\text {st }}$ variationDye Titanium Dioxide
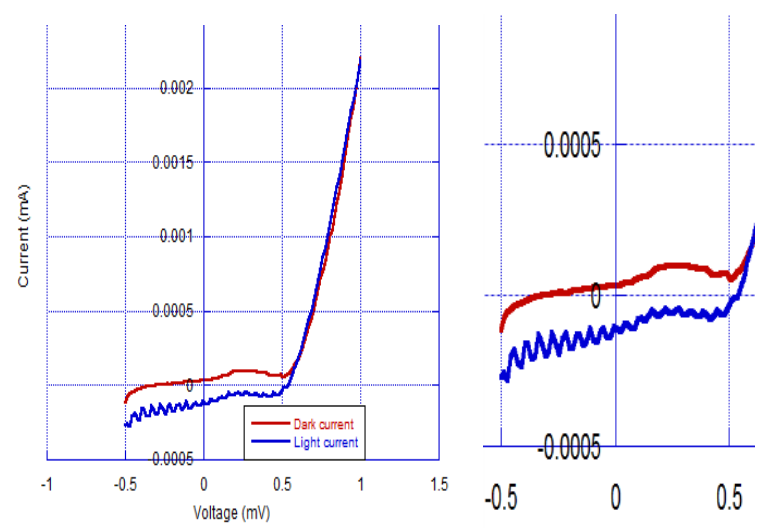

Figure 3. Current-voltage curves of the $2^{\text {nd }}$ variation Dye Titanium Dioxide

Figure 2 and 3 indicates that the I-V curves with the higher volume of dye (second variation) have a greater curve between dark and light current (Figure 3) than the first variation 1 (Figure 2). It means that the efficiency of the second variation is greater than the first variation. To determine energy conversion efficiency was using Equation (1) (Gong et al., 2012):

$$
\eta=\frac{P_{\max }=V_{\max } I_{\max }}{P_{\text {Light }}} \times 100 \%
$$

Table 1. Performance parameters of dye titanium dioxide

\begin{tabular}{ccc}
\hline $\begin{array}{c}\text { Variation of- } \\
-\end{array}$ & I & II \\
\hline$I_{s c}$ & $0,1 \mathrm{~mA}$ & $0,1 \mathrm{~mA}$ \\
$V_{o c}$ & $430 \mathrm{mV}$ & $550 \mathrm{mV}$ \\
$I_{\max }$ & $0,07 \mathrm{~mA}$ & $0,08 \mathrm{~mA}$ \\
$V_{\max }$ & $295 \mathrm{mV}$ & $415 \mathrm{mV}$ \\
\hline Efficiency & $0,023 \%$ & $0,033 \%$ \\
\hline
\end{tabular}

As observed in Table 1, the efficiency, current and voltage of the second variation was higher than the first variation. But the value of efficiency is still lowest than the research by Ananth and co-workers with similar method. This is due to many factors, 
such as less homogeneous solution, volume mixing $\mathrm{TiO}_{2}$ with dye is not right, and the thickness of the semiconductor layer.

\section{Conclusion}

The comparison of volume mixture $\mathrm{TiO}_{2}$ with dye affects the value of absorbance and efficiency. The dye Rhoeo spathacea exhibited a good absorption peak in the visible region at $665 \mathrm{~nm}$ and $413 \mathrm{~nm}$. The absorption peak of dye is shifting which gets suppressed when dye mixed with $\mathrm{TiO}_{2}$ and gets the different value for variation volume. The dye titanium dioxide exhibited a good absorption peak between the end of UV region $(340 \mathrm{~nm})$ and the beginning of visible region $(386 \mathrm{~nm})$. The performance of the dye titanium dioxide achieved an efficiency of $0,033 \%$ for the second variation and $0,023 \%$ for the first variation. It means that the higher volume dye can increase the value of efficiency.

\section{Acknowledgement}

This Research was partly supported by Higher Education Project Grant with contract no. 343/UN27/HK/2016.

\section{References}

Ananth, S., Arumanayagam, T., Vivek, P., Murugakoothan, P. (2014). Direct Synthesis of Natural Dye Mixed Titanium Dioxide Nano-Particles by Sol-gel Method for Dye Sensitized Solar Cell Application. Optik, vol. 125, pp. 495-498.

Agustini, S., Risanti ,D.D, Sawitri, D. (2013). Fabrikasi Dye Sensitized Solar Cell (DSSC) Berdasarkan Fraksi VolumeTiO 2 Anatase-Rutile dengan Garcinia mangostana dan Rhoeo spathacea sebagai Dye Fotosensitizer. Jurnal Teknik Pomits, vol. 2, No. 2, pp. 131-136.

Benanti, Travis, L, Venkataraman, D. (2006). Organic Solar Cells: An Overview Focusing on Active Layer Morphology. Photosynthesis Research, vol. 87, pp. 73-81.

Ekasari, V, Yudoyono, G. (2013). Fabrikasi DSSC dengan Dye Ekstrak Jahe Merah (Zingiber Officinale Linn Va. Rubrum) Variasi Larutan $\mathrm{T}_{i} \mathrm{O}_{2}$ Nanopartikel Berfase Anatase dengan Teknik Pelapisan Spin Coating. Jurnal Sains dan Seni Pomits, vol. 2, no. 1, pp. 2337-3520.

Gong, J, Liang, J, Sumathy, K. (2012). Review on Dye-Sensitized Solar Cells (DSSC) : Fundamental Concepts and Novel Materials. Renewable and Sustainable Energy Reviews, vol. 16, pp. 5848-5860.

Gratzel.M. (2003). Dye-Sensitized Solar Cells.Journal of Photochemistry and Photobiology C:Photochemistry, vol. 4, pp. 145-153.

Hemmatzadeh, R, Mohammadi, A. (2013). Improving optical absorptivity of natural dyes for fabrication of efficient dye-sensitized solar cells. Journal of Theoretical and Applied Physic, vol. 7, pp. 57-64.

Kartikasari. (2014). Pengaruh Penambahan Dye Sansiviera Trifasciata pada Lapisan Titanium Dioksida terhadap Penurunan Celah Pita Energi. Prosiding Ilmiah 
XXVIII HFI Jateng dan DIY, hlm. 261-263.

Kang, M., Lee, Y. (2010). The Optical Properties of Nanoporous Structured Titanium Dioxide and the Photovoltaic Efficiency on DSSC. Materials Chemistry and Physics, vol. 122, pp.284-289.

Smestad, G.P., Gratzel, M. (1998). Demonstrating Electron Transfer and Nanotechnology : A Natural Dye-Sensitized Nanocrystalline Energy Converter. Journal Chemical Education, vol. 45, pp. 752.

Syafinar, R., Gomesh, N., Irwanto, M., Fareq, M., danIrwan, Y.M. (2015). Chlorophyll Pigments as Nature Based Dye for Dye-Sensitized Solar Cell (DSSC). Energy Procedia, vol. 79, pp. 896-902 